\title{
Requirement of $\mathrm{N}$-glycosylation of the prostaglandin $\mathrm{E}_{2}$ receptor EP3 $\beta$ for correct sorting to the plasma membrane but not for correct folding
}

\author{
Ulrike BÖER*, Frank NEUSCHÄFER-RUBE*, Ulrike MÖLLER $\dagger$ and Gerhard P. PÜSCHEL ${ }^{* 1}$ \\ *Universität Potsdam, Institut für Ernährungswissenschaft, Arthur-Scheunert-Allee 114-116, D-14558 Bergholz-Rehbrücke, Germany, and †Georg-August-Universität, \\ Institut für Biochemie und Molekulare Zellbiologie, Humboldtallee 23, D-37073 Göttingen, Germany
}

Eight heptahelical receptors have been characterized for prostaglandin $(\mathrm{PG}) \mathrm{D}_{2}, \mathrm{PGE}_{2}, \mathrm{PGF}_{2 \alpha}$, prostacyclin and thromboxane $\mathrm{A}_{2}$. They share a sequence identity of $40 \%$. All of them have potential $\mathrm{N}$-glycosylation sites. The current study analysed the role of the two $\mathrm{N}$-glycosylation sites in the rat EP3 $\beta$-subtype $\mathrm{PGE}_{2}$ receptor for protein folding and sorting. The $\mathrm{N}$ glycosylation consensus sequences were eliminated by sitedirected mutagenesis and receptors expressed in HEK-293 cells. Both potential N-glycosylation sites were used. Their joint elimination resulted in the synthesis of a receptor protein with full binding competence, biological activity and no reduction of affinity; however, the half-life of the non-glycosylated receptor was slightly reduced. Ligand binding to intact stably transfected cells and confocal laser microscopic immunocytochemistry showed that the glycosylated receptor was correctly inserted into the plasma membrane to a much larger extent than the nonglycosylated receptor, which tended to accumulate in the perinuclear zone of the endoplasmic reticulum. Inhibition of $\mathrm{N}$ glycosylation with tunicamycin resulted in a similar perinuclear distribution of the wild-type receptor. Therefore, glycosylation of the EP $3 \beta$ receptor seems not to be necessary for correct folding of the receptor protein but for the efficient transport of the receptor protein to the plasma membrane. This contrasts with a previous finding which described a reduction of the affinity for $\mathrm{PGE}_{2}$ of the $\mathrm{EP} 3 \alpha$ receptor by elimination of the distal glycosylation site when the receptor protein was expressed in insect cells.

Key words: confocal laser microscopy, immunocytochemistry, site-directed mutagenesis, structure-function analysis.

\section{INTRODUCTION}

Prostaglandins (PGs) are cyclo-oxygenase products of the $\mathrm{C}_{20}$ fatty acid arachidonic acid. They act as locally active signal substances and modulate cellular functions in homoeostasis and inflammation. They act on their target cells via heptahelical receptors that couple to heterotrimeric G-proteins [1]. Eight heptahelical prostanoid receptor subtypes have been cloned so far, one each for $\mathrm{PGD}_{2}, \mathrm{PGF}_{2 \alpha}$, prostacyclin $\left(\mathrm{PGI}_{2}\right)$ and thromboxane $\mathrm{A}_{2}$ and four for $\mathrm{PGE}_{2}$ [2]. The receptors of this family only display an overall sequence similarity of about $40 \%$, the transmembrane domains being most conserved [3]. Several other structural motifs are conserved among all prostanoid receptor subtypes or are particular to a certain subtype and their function has been elucidated by site-directed-mutagenesis-based alteration of these sites [4]. Of all prostanoid receptors the EP3 $\beta$-subtype $\mathrm{PGE}_{2}$ receptor (EP3-R) is best characterized. An Arg and an Asp in the seventh transmembrane domain have been identified as essential for ligand binding and G-protein coupling [5]. A stretch of eight amino acids in the second extracellular loop that is conserved among all EP (E-series prostanoid) receptors seems to confer $\mathrm{PGE}_{2}$ binding specificity [6]. The C-terminal domain is essential for G-protein-coupling control but not for G-proteincoupling specificity [7]. All prostanoid receptors have conserved $\mathrm{N}$-glycosylation sites in the $\mathrm{N}$-terminal domain and either one of the extracellular loops. The EP3-R has two potential glycosylation sites in the N-terminal domain and the second extracellular loop close to the stretch of amino acids that confers ligand-binding specificity [8]. Before the current study it was not clear whether these glycosylation sites were used or what their function might be. Studies with cell lines naturally expressing a $\mathrm{PGE}_{2}$ receptor not identified at the molecular level, in which protein glycosylation had been inhibited with tunicamycin, indicated that receptor glycosylation might be essential for correct folding and correct insertion of the receptor into the plasma membrane [9]. Site-directed-mutagenesis studies analysing the function of glycosylation sites in other G-protein-coupled receptors revealed that the requirement of $\mathrm{N}$-glycosylation for correct folding and insertion into the plasma membrane differs between different receptors. Thus N-glycosylation seemed to be essential in $\beta 2$-adrenergic receptors [10], whereas it was not necessary for expression of functional $\mathrm{m} 2$ muscarinic receptors [11] or the $\mathrm{H} 2$ histamine receptor [12]. Therefore it was the purpose of the current study to investigate the role of the potential glycosylation sites of the $\mathrm{EP} 3 \beta$-R by ablating these sites by site-directed mutagenesis.

It was found that $\mathrm{N}$-glycosylation was not required for the correct synthesis of a fully functional receptor protein; however, glycosylation was essential for efficient translocation of the receptor protein to the plasma membrane. The current results are at variance with the previously published observation that the elimination of $\mathrm{N}$-glycosylation sites in the rat EP $3 \alpha-\mathrm{R}$ expressed in insect cells led to a reduction of the receptor's affinity for $\mathrm{PGE}_{2}$ [13].

\section{EXPERIMENTAL PROCEDURES}

\section{Materials}

All materials were of analytical or molecular-biological grade and from commercial sources. HPLC-purified PCR primers were custom-synthesized by NAPS (Göttingen, Germany). M\&B 28767 was a gift from Rhone-Poulenc Rorer (Dagenham, Essex,

Abbreviations used: PG, prostaglandin; EP3 $\beta$-R, EP3 $\beta$-subtype PGE 2 receptor; Cy3, indocarbocyanine; PVDF, poly(vinylidene difluoride); ER, endoplasmic reticulum.

To whom correspondence should be addressed (e-mail gpuesche@rz.uni-potsdam.de). 


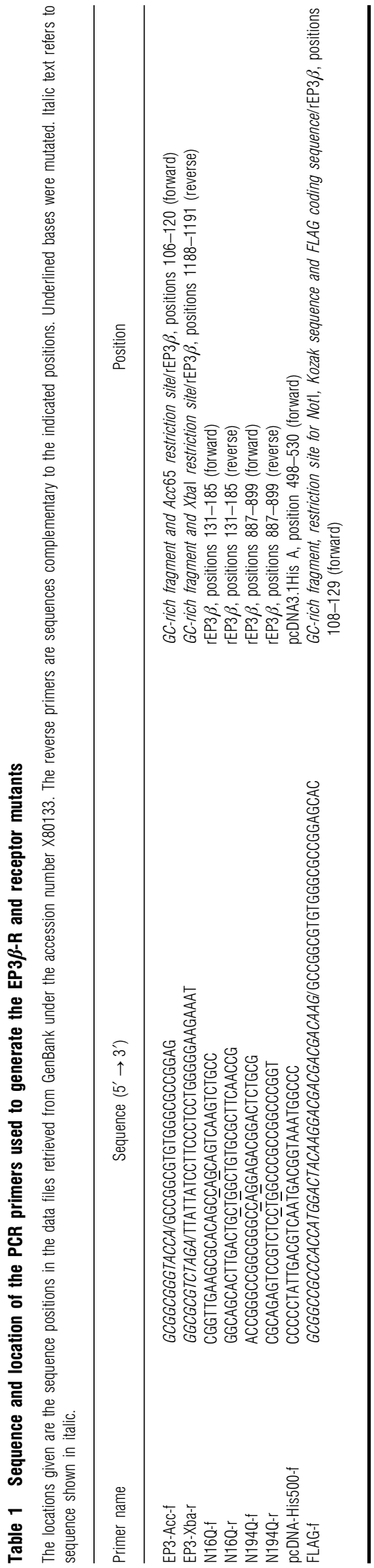

U.K.). $\left[{ }^{3} \mathrm{H}\right] \mathrm{PGE}_{2}$ and $\left[{ }^{35} \mathrm{~S}\right]$ methionine/cysteine ('Pro-mix') were obtained from Amersham (Braunschweig, Germany); unlabelled PGs were purchased from Serva (Heidelberg, Germany) or Calbiochem-Novabiochem (Bad Soden, Germany), who also provided Geneticin (G-418 sulphate) and forskolin. Cell-culture media were obtained from Gibco-BRL (Eggenstein, Germany), and tunicamycin and trypsin were from Sigma (Deisenhofen, Germany), who also provided the monoclonal FLAG-M2 antibody. N-Hydracid-biotin was obtained from Pierce (Frankfurt A. M., Germany). The sources of other materials are given elesewhere in the text. The eukaryotic expression vectors pcDNA3.1His, pRc/CMV and pCDNA1 were purchased from Invitrogen (Leek, The Netherlands). The antibodies against calreticulin [for labelling of the endoplasmic reticulum (ER)] and the KDEL receptor (for labelling of the Golgi apparatus) where provided by Professor H. D. Söling (Max Planck Institut für Biophysikalische Chemie, Göttingen, Germany).

\section{Site-directed mutagenesis and attachment of a FLAG-epitope tag}

A PCR fragment containing the entire translated region of the rat (r) EP3 $\beta$-R cDNA was generated with the primers EP3Acc-f and EP3-Xba-r (Table 1) and cloned into the Acc65-XbaI site of the vector pcDNA3.1His. Both potential glycosylation sites of the receptor were eliminated independently by PCR-based site-directed mutagenesis with proof-reading $P$ wo polymerase and the following program: $3 \mathrm{~min}$ at $95^{\circ} \mathrm{C}, 35$ cycles of $1 \mathrm{~min}$ at $95^{\circ} \mathrm{C}, 1 \mathrm{~min}$ at $58^{\circ} \mathrm{C}$ and $2 \mathrm{~min}$ at $72^{\circ} \mathrm{C}$, and a final extension for $10 \mathrm{~min}$ at $72^{\circ} \mathrm{C}$. For each mutant, two overlapping PCR products containing the mutation in the overlap region were synthesized and then fused by a subsequent PCR with the two flanking primers.

For mutant N16Q, a 530-bp 5' fragment was generated with a forward primer corresponding to a sequence $500 \mathrm{bp}$ upstream of the start codon in the vector pcDNA-His500-f (Table 1) and a reverse primer containing the mutation N16Q (N16Q-r, Table 1). A $3^{\prime}$ fragment was produced with the forward primer covering the mutation site (N16Q-f, Table 1) and the primer EP3-Xba-r. A PCR product containing the entire open reading frame was then generated with both overlapping fragments as template and the primers pcDNA-His500-f and EP3-Xba-r. The PCR product was purified, digested overnight with $A c c 65$ and $X b a \mathrm{I}$ and then ligated into the $A c c 65-X b a \mathrm{I}$ site of pcDNA3.1His. For mutant N194Q, the $5^{\prime}$ portion was synthesized with the primer pair EP3Acc-f and N194Q-r (Table 1), the 3' portion with the primer pair N194Q-f (Table 1) and EP3-Xba-r. The two flanking primers were used to generate the cDNA fragment with the entire reading frame, which was ligated into pcDNA3.1His after $A c c 65 / X b a \mathrm{I}$ digestion. A mutant lacking both potential glycosylation sites was generated using the approach for the N16Q mutant with the N194Q mutant as template. To introduce a suitable epitope tag for immunological detection, the wild-type receptor sequence and the three mutant sequences were re-amplified using the pcDNA3.1His constructs as templates, a forward primer (FLAGf) that starts at the second translated codon of the EP3 receptor and possesses a $5^{\prime}$ overhanging sequence coding for a NotI site, a Kozak sequence and a FLAG tag (FLAG epitope Asp-TyrLys-Asp-Asp-Asp-Asp-Lys, Table 1) and the reverse primer EP3-Xba-r. Taq polymerase was used in the following program: $3 \mathrm{~min}$ at $95^{\circ} \mathrm{C}, 35$ cycles of $1 \mathrm{~min}$ at $95^{\circ} \mathrm{C}, 1 \mathrm{~min}$ at $60^{\circ} \mathrm{C}$ and $2 \mathrm{~min}$ at $72{ }^{\circ} \mathrm{C}$, and a final extension for $10 \mathrm{~min}$ at $72^{\circ} \mathrm{C}$. The PCR products were digested with $N o t \mathrm{I}$ and $\mathrm{XbaI}$ and ligated into the Not I-XbaI site of $\mathrm{pRc} / \mathrm{CMV}$. The sequences of the final products were verified by cycle sequencing with an automated Perkin-Elmer sequencer. 


\section{Transient and stable expression of the mutants in HEK-293 cells}

The constructs $\mathrm{pRc} / \mathrm{CMV}-\mathrm{EP} 3 \beta, \quad \mathrm{pRc} / \mathrm{CMV}-\mathrm{EP} 3 \beta-\mathrm{N} 16 \mathrm{Q}$, $\mathrm{pRc} / \mathrm{CMV}-\mathrm{EP} 3 \beta$-N194Q and $\mathrm{pRc} / \mathrm{CMV}-\mathrm{EP} 3 \beta$-N16/194Q were transfected into HEK-293 cells by the calcium phosphate method using $5 \%(\mathrm{v} / \mathrm{v})$ modified bovine serum from Stratagene (Heidelberg, Germany). Transfectants stably expressing either the wild-type $\mathrm{EP} 3 \beta$-R or the $\mathrm{EP} 3 \beta$-N16/194Q mutant receptor (EP3 $\beta$-N16/194Q-R) were isolated in Dulbecco's modified Eagle's medium containing $10 \%(\mathrm{v} / \mathrm{v})$ fetal calf serum and $0.5 \mathrm{mg} / \mathrm{ml} \mathrm{G}-418$ as substrate of the selection marker aminoglycoside phosphotransferase (NEO). Clonal cell lines were isolated by single-cell cloning and tested for receptor expression by $\mathrm{PGE}_{2}$ binding.

\section{Membrane preparation}

Cells stably expressing one of the receptor proteins or cells transiently transfected $72 \mathrm{~h}$ previously were homogenized in a homogenization buffer containing $10 \mathrm{mM}$ Tris/ $\mathrm{HCl}, \mathrm{pH} 7.5$, $250 \mathrm{mM}$ sucrose, $10 \mathrm{mM} \mathrm{MgCl}_{2}, 1 \mathrm{mM}$ EDTA and $1 \mathrm{mM}$ pefabloc (Biomol, Hamburg, Germany) with a Dounce homogenizer. The homogenate was centrifuged at $100000 \mathrm{~g}$ and the resulting crude-membrane fraction was suspended in binding buffer containing $10 \mathrm{mM}$ Mes/NaOH, pH 6.2, $10 \mathrm{mM} \mathrm{MgCl}_{2}$ and $1 \mathrm{mM}$ EDTA and stored at $-20^{\circ} \mathrm{C}$.

\section{Western-blot analysis}

Membranes of transfected cells (containing about $75 \mathrm{fmol}$ of receptor protein as determined by binding assay) were incubated for $60 \mathrm{~min}$ at $37^{\circ} \mathrm{C}$ and $10 \mathrm{~min}$ at $60^{\circ} \mathrm{C}$ in a sample buffer containing $80 \mathrm{mM}$ Tris $/ \mathrm{HCl}, \mathrm{pH} 6.8,2 \%$ SDS, $2 \mathrm{M}$ urea and $5 \%$ mercaptoethanol. Proteins were separated by SDS/PAGE (10\% gel) and then blotted on to a poly(vinylidene difluoride) (PVDF) membrane (Millipore, Neu-Isenburg, Germany). Blots were incubated with the monoclonal anti-FLAG-M2 antibody $(0.3 \mu \mathrm{g} / \mathrm{ml})$ for $12 \mathrm{~h}$ at $4{ }^{\circ} \mathrm{C}$ followed by a peroxidase-coupled secondary antibody (Bio-Rad, München, Germany) in a 1:20000 dilution for $1 \mathrm{~h}$ at room temperature. Immunoreactive bands were visualized with the ECL system (Amersham).

\section{Immunoprecipitation}

Following transient transfection $(12 \mathrm{~h})$, cells were metabolically labelled for $1 \mathrm{~h}$ with $1.1 \mathrm{mCi} / \mathrm{ml} \quad\left[{ }^{35} \mathrm{~S}\right]$ methionine/cysteine $\left(286 \mu \mathrm{Ci} / 5 \times 10^{6}\right.$ cells $)$ in methionine/cysteine-depleted Dulbecco's modified Eagle's medium followed by a chase in the presence of excess unlabelled methionine/cysteine for 0,12 and $24 \mathrm{~h}$. Cells were washed extensively and incubated for $1 \mathrm{~h}$ at $4{ }^{\circ} \mathrm{C}$ in a lysis buffer $\left(800 \mu \mathrm{l} / 5 \times 10^{6}\right.$ cells $)$ containing $50 \mathrm{mM}$ Tris $/ \mathrm{HCl}$, $\mathrm{pH} 8.0,150 \mathrm{mM} \mathrm{NaCl}, 5 \mathrm{mM}$ EDTA, $1 \%$ Triton $\mathrm{X}-100$ and $0.05 \%$ SDS. After centrifugation at $20000 \mathrm{~g}$, the supernatant of this solubilization was pre-absorbed for $1 \mathrm{~h}$ with $1.1 \%$ (final concentration) Protein G-Sepharose (Pharmacia, Freiburg, Germany). Receptor proteins were then immunoprecipitated with $1 \%$ Protein G-Sepharose and $15 \mu \mathrm{g}$ of FLAG-M2 antibody for $2 \mathrm{~h}$ at $4{ }^{\circ} \mathrm{C}$, separated by SDS/PAGE $(10 \%$ gel) and visualized by autoradiography with a PhosphoImager (STORM, Amersham) after 3 days of exposure. Stably transfected cells were grown to confluence on $8.7-\mathrm{cm}^{2}$ plates, labelled as described above, lysed with lysis buffer containing $50 \mathrm{mM}$ Hepes, $\mathrm{pH} 7.5$, $150 \mathrm{mM} \mathrm{NaCl}, 5 \mathrm{mM}$ EDTA, $0.5 \%$ (v/v) Nonidet P40, $0.5 \%$ $(\mathrm{w} / \mathrm{v})$ sodium deoxycholate and $0.1 \%(\mathrm{w} / \mathrm{v})$ SDS and immunoprecipitated with a peptide-specific polyclonal antiserum against the $13 \mathrm{C}$-terminal amino acids of the receptor protein $(15 \mu \mathrm{g}$ of $\mathrm{IgG}$ ).

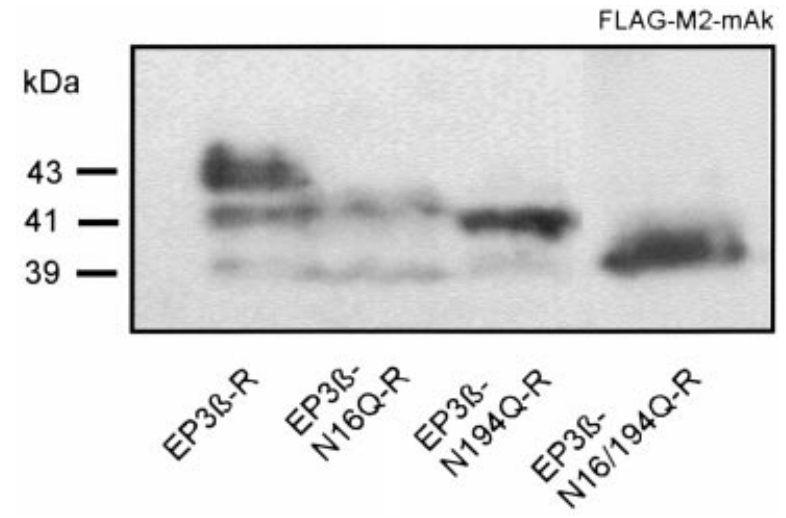

Figure 1 Determination of the apparent molecular masses of EP3 $\beta$-R, EP3 $\beta$-N16Q-R, EP3 $\beta-\mathrm{N} 194 Q-\mathrm{R}$ and EP3 $\beta$-N16/194Q-R in transiently transfected cells

HEK-293 cells were transiently transfected with cDNAs of FLAG-tagged wild-type or mutated receptors in the eukaryotic expression vector pRc/CMV. After transfection (72 h) cells were harvested and a crude membrane fraction was prepared by differential centrifugation. Proteins were separated on a $10 \%$ polyacrylamide gel and transferred on to PVDF membranes by electroblotting. Receptor proteins were detected with monoclonal anti-FLAG antibody. Blots were developed with a peroxidase-coupled secondary antibody and the ECL system.

\section{Northern-blot analysis}

mRNAs corresponding to $50 \mu \mathrm{g}$ of total RNA from $5 \times 10^{6}$ cells stably expressing the EP3 $\beta$-R or EP3 $\beta$-N16/194Q-R were prepared by sequential affinity chromatography using the RNeasy and the Oligotex-dT kits (Qiagen, Hilden, Germany). mRNAs were separated on denaturing formaldehyde gels and transferred to Amersham Hybond $\mathrm{N}$ nylon membranes. EP3 $\beta$-R mRNA was detected by hybridization at $65^{\circ} \mathrm{C}$ for $12 \mathrm{~h}$ with digoxigeninlabelled complementary RNA probes $(50 \mathrm{ng} / \mathrm{ml})$, which were generated by in vitro transcription from an $\mathrm{XbaI}$-linearized plasmid encoding the last $600 \mathrm{bp}$ of EP3 $\beta$-R cDNA, pBS-EP3, using T7 RNA polymerase and digoxigenin-labelled UTP. As an internal control $\beta$-actin mRNA was hybridized with a $\beta$-actin RNA probe (Boehringer Mannheim, Mannheim, Germany). Hybridized probes were detected with alkaline phosphataselabelled anti-digoxigenin antibody with a chemiluminescent substrate reaction as provided in a detection kit (Boehringer/ Roche Mannheim). Signals were quantified video-densitometrically.

\section{Binding assays}

Ligand-binding assays were performed with crude membranes, with lysed cells or with intact cells stably expressing the EP3 $\beta$-R or the EP3 $\beta$-N16/194Q-R. For ligand-binding assay with lysed cells, cells were detached from the tissue-culture plates with icecold incubation buffer containing $15 \mathrm{mM}$ Hepes, $\mathrm{pH} 7.4,140 \mathrm{mM}$ $\mathrm{NaCl}, 4.7 \mathrm{mM} \mathrm{KCl}, 2.2 \mathrm{mM} \mathrm{CaCl}, 1.2 \mathrm{mM} \mathrm{K \textrm {K } _ { 2 }} \mathrm{PO}_{4}$ and $11 \mathrm{mM}$ glucose at a density of $5 \times 10^{6}$ cells $/ \mathrm{ml}$. Where indicated, cells were incubated with $1 \mu \mathrm{g} / \mathrm{ml}$ tunicamycin $24 \mathrm{~h}$ prior to harvest.

Filter-binding assays with membranes (about 20-50 $\mu \mathrm{g}$ of protein) or lysed cells $\left(5 \times 10^{5}\right)$ were performed essentially as described previously [8] with $5 \mathrm{nM}\left[{ }^{3} \mathrm{H}\right] \mathrm{PGE}_{2}$ and various concentrations of unlabelled $\mathrm{PGE}_{2}$ in $100 \mu \mathrm{l}$ of binding or incubation buffer respectively for $30 \mathrm{~min}$ at $37^{\circ} \mathrm{C}$. Binding constants were calculated by non-linear regression analysis (LIGAND [14]).

For ligand-binding assays with intact cells the cells were grown to confluence on $8.7-\mathrm{cm}^{2}$ culture plates, washed twice with ice- 

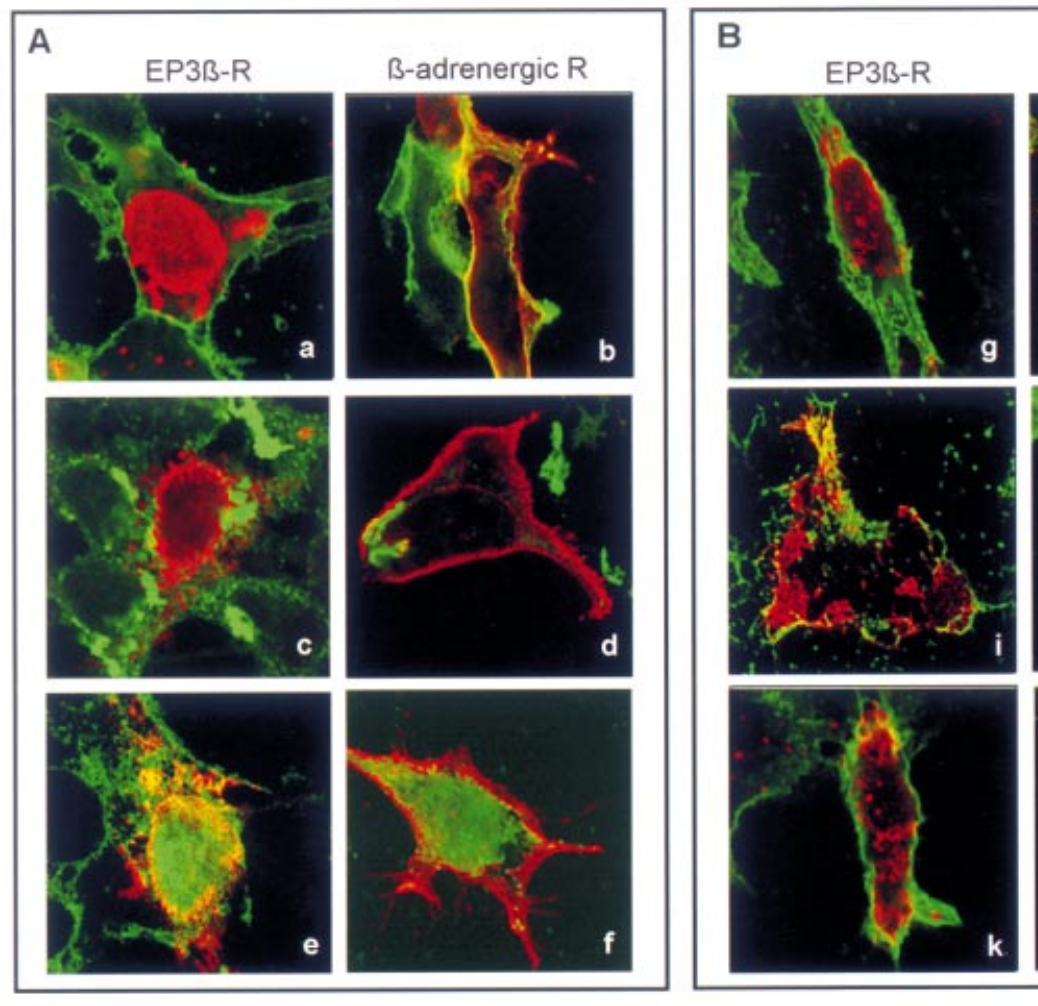

\section{B-adrenergic R}
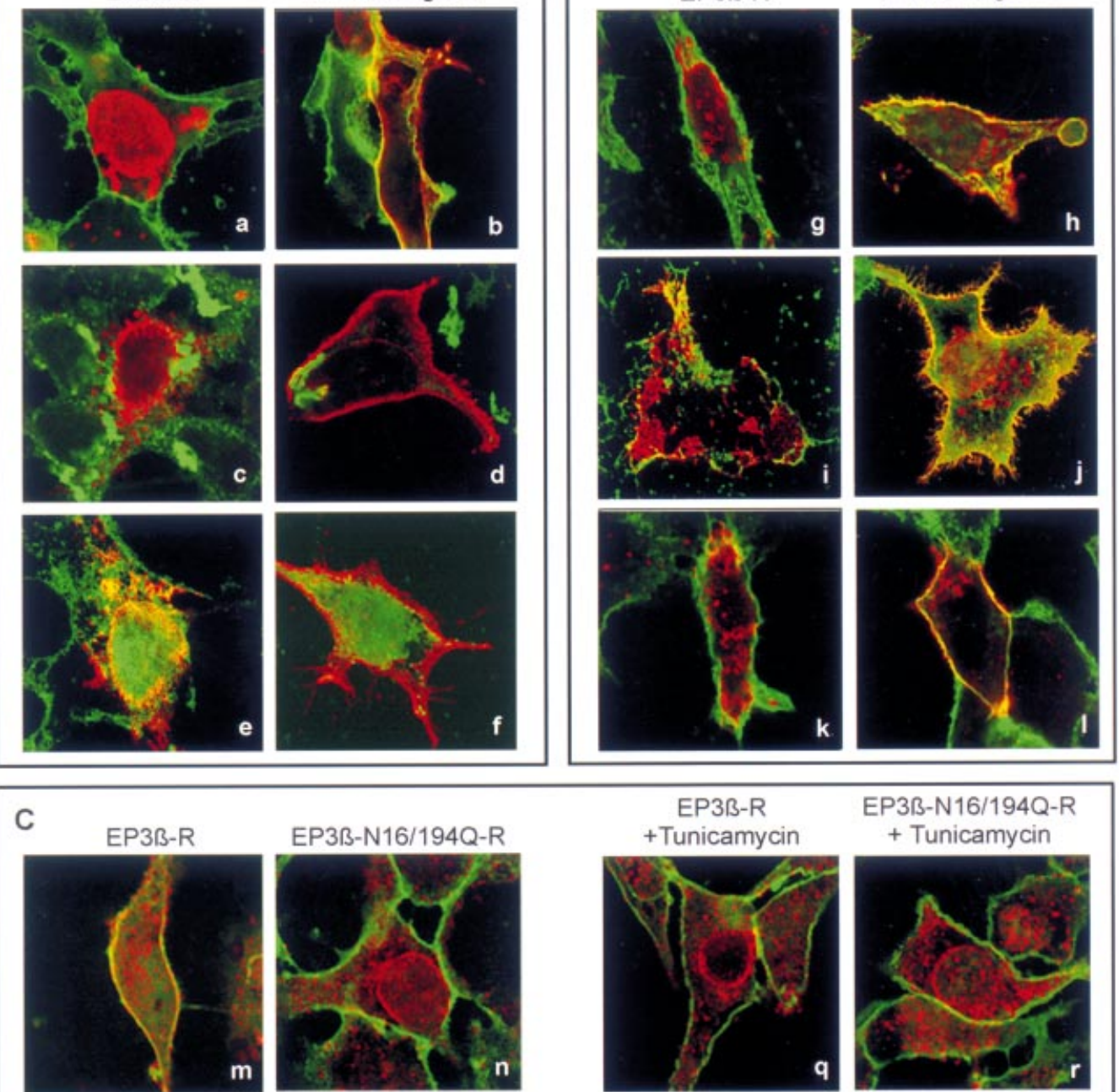

EP3ß-N16/194Q-R

EP3ß-R

EP3ß-N16/194Q-R

+Tunicamycin

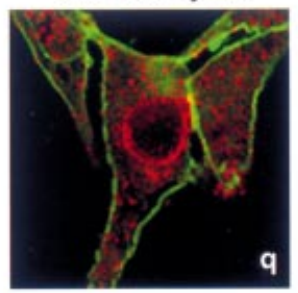

+ Tunicamycin
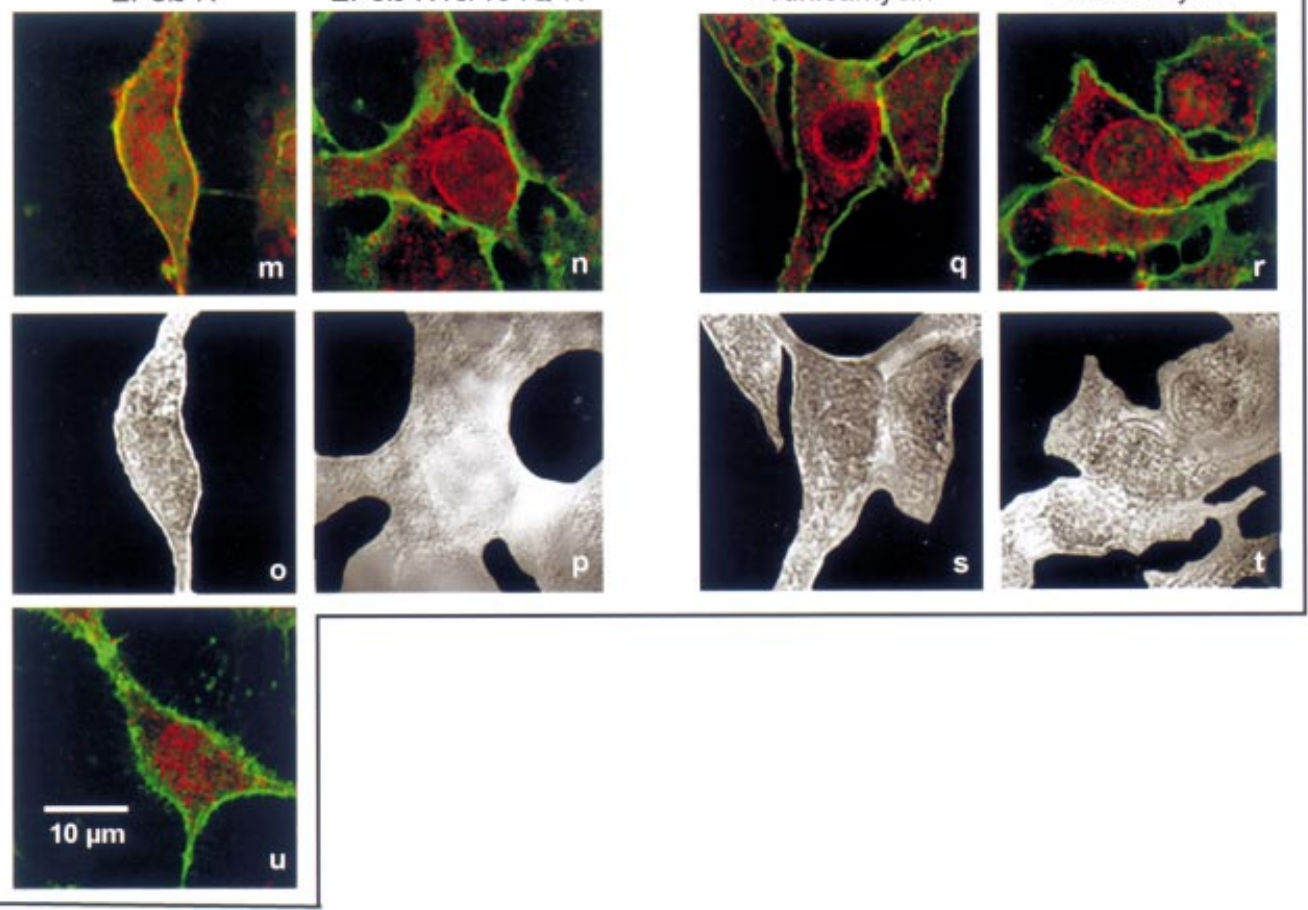

Figure 2 Cytochemistry of cells transiently and stably expressing the EP3 $\beta$-R and EP3 $\beta$-N16/194Q-R proteins

(A) HEK-293 cells were cultured on coverslips and transfected with the cDNAs of the respective receptors in the eukaryotic expression vectors pRc/CMV (EP3 $\beta$-R and EP3 $\beta$-N16/194Q-R) and pCDNA1 ( $\beta$-adrenergic receptor). After transfection ( $24 \mathrm{~h}$ ), the intact cells were biotinylated for later detection of the plasma membranes with streptavidin-FITC (panels a and b). After fixation, receptor proteins were detected with the monoclonal FLAG-M2 antibody and a Cy3-labelled secondary antibody. Marker proteins for Golgi apparatus (KDEL receptor, panels $\mathrm{c}$ and d) and ER (calreticulin, panels e and f) were detected with polyclonal rabbit antisera and a FITC-labelled secondary antibody. The slides were analysed by confocal laser microscopy. The markers for plasma membrane, ER and Golgi apparatus appear green, the receptor proteins red. Co-localization of receptors and the subcellular marker appears yellow. Whereas EP3 $\beta$-R and EP3 $\beta$-N16/194Q-R were found almost exclusively in a narrow ring of the ER around the nucleus, the $\beta$-adrenergic receptor appeared to be located in the plasma membrane. (B) HeLa-cells (panels $\mathrm{g}$ and $\mathrm{h}$ ), COS-7 cells (panels $\mathrm{i}$ and j) and HepG2 cells (panels $k$ and I) were cultured on coverslips and transiently transfected with the cDNAs of the respective receptors. After transfection (24 h), cells were labelled as described for (A), panels (a) and (b). In all cell types, EP3 $\beta$-R and EP3 $\beta$-N16/194Q-R were found in the perinuclear region whereas the $\beta$-adrenergic receptor appeared in the plasma membrane. 
cold incubation buffer and then incubated for $1 \mathrm{~h}$ at $4{ }^{\circ} \mathrm{C}$ with $5 \mathrm{nM}\left[{ }^{3} \mathrm{H}\right] \mathrm{PGE}_{2}$. Non-specific binding was determined in the presence of $10 \mu \mathrm{M} \mathrm{PGE}_{2}$. Culture plates were washed three times with ice-cold incubation buffer and solubilized in $5 \%$ Triton $\mathrm{X}-100$. Radioactivity retained on intact cells was counted in $5 \mathrm{ml}$ of Hydroluma.

\section{Inhibition of forskolin-induced cAMP formation}

Cells stably expressing the EP3 $\beta$-R or the EP3 $\beta$-N16/194Q-R were cultured in $8.7-\mathrm{cm}^{2}$ plates to a density of $5 \times 10^{5}$ cells. Cells were washed three times in incubation medium and then pre-incubated in $1 \mathrm{ml}$ of the same buffer with $1 \mathrm{mM}$ isobutylmethylxanthine at $37^{\circ} \mathrm{C}$ for $10 \mathrm{~min}$. Then $\mathrm{M} \& \mathrm{~B} 28767$ and forskolin were added in $10 \mu \mathrm{l}$ of buffer to final concentrations of $10^{-8}-10^{-12} \mathrm{M}$ and $1 \mu \mathrm{M}$ respectively. After $10 \mathrm{~min}$ the reaction was stopped by freezing the cells in liquid nitrogen. Cells were lysed in $500 \mu \mathrm{l}$ of $10 \mathrm{mM} \mathrm{HCl}$ containing $1 \mathrm{mM}$ isobutylmethylxanthine for $1 \mathrm{~h}$ at $4{ }^{\circ} \mathrm{C}$. The lysate was centrifuged and cAMP was quantified in the supernatant with a $\left[{ }^{125} \mathrm{I}\right] \mathrm{cAMP}$ assay kit from Amersham.

\section{Receptor localization by immunofluorescence}

HEK-293 cells, HeLa cells, COS-7 cells or HepG2 cells were plated on coverslips at densities of $2 \times 10^{4}, 3.6 \times 10^{4}, 1.6 \times 10^{4}$ and $2.6 \times 10^{4}$ cells $/ \mathrm{cm}^{2}$ respectively, cultured for $24 \mathrm{~h}$ and then transfected with the receptor cDNA constructs as described above. After transfection $(24 \mathrm{~h})$, cells were fixed with $4 \%$ paraformaldehyde in PBS for $15 \mathrm{~min}$. They were subsequently permeabilized with $0.1 \%$ saponin in PBS for $15 \mathrm{~min}$. After blocking with goat serum for $1 \mathrm{~h}$ cells were incubated with the monoclonal mouse anti-FLAG-M2 antibody $(5 \mu \mathrm{g} / \mathrm{ml})$ at $37^{\circ} \mathrm{C}$ for $60 \mathrm{~min}$ and either the polyclonal rabbit anti-calreticulin or rabbit anti-KDEL receptor antibody at a 1:25 dilution as indicated. Bound antibody was then visualized with secondary FITC-labelled goat anti-rabbit antibodies and indocarbocyanine (Cy3)-labelled goat anti-mouse antibodies in dilutions of $1: 40$ and 1:200 respectively. For plasma-membrane labelling, intact cells were biotinylated with $\mathrm{N}$-hydracid-biotin prior to fixation and later incubated with streptavidin-FITC at a 1:75 dilution to visualize plasma membranes. All antibodies were diluted in PBS containing $1 \%$ BSA. Coverslips were finally mounted in mounting medium containing $5 \%(\mathrm{w} / \mathrm{v})$ mowiol (Calbiochem, Frankfurt A.M., Germany), $33 \%(\mathrm{w} / \mathrm{w})$ glycerol and $5 \%(\mathrm{w} / \mathrm{v})$ diazabicyclo-octan (Sigma).

In cells stably expressing the $\mathrm{EP} 3 \beta-\mathrm{R}$ or the $\mathrm{EP} 3 \beta-\mathrm{N} 16 /$ 194Q-R, proteins were detected by incubation with a polyclonal antiserum against the $\mathrm{N}$-terminal receptor domain at a concentration of $25 \mu \mathrm{g} / \mathrm{ml}$ and a Cy3-coupled secondary antibody.

\section{RESULTS}

The Asn residues of both N-glycosylation consensus sequences of the EP $3 \beta$-R were replaced separately or jointly with Gln by PCR-based site-directed mutagenesis, yielding the constructs EP3 $\beta$-R (wild-type), EP3 $\beta$-N16Q-R (lacking the N-glycosylation site in the N-terminal receptor domain), EPR $\beta$-N194Q-R (lacking the N-glycosylation site in the second extracellular loop) and EP3 $\beta$-N16/194Q-R (lacking both potential glycosylation sites). Wild-type and modified receptor cDNAs were cloned into the eukaryotic expression vector $\mathrm{pRc} / \mathrm{CMV}$ and expressed transiently in HEK-293 cells. After transfection (72 h), a crude membrane fraction was prepared from cell homogenates. The membranes of wild-type and all mutant receptors specifically bound $\mathrm{PGE}_{2}$ with a comparable specific maximal binding of about $0.6-3 \mathrm{fmol} / \mu \mathrm{g}$ (results not shown). After transient transfection, receptor proteins could be detected in Western blots with the FLAG-M2 antibody. The wild-type EP3 $\beta$-R appeared as three distinct bands with apparent molecular masses of 43,41 and $39 \mathrm{kDa}$ (Figure 1). Both receptors lacking either one of the glycosylation sites appeared as a doublet of 41 and $39 \mathrm{kDa}$, whereas the EP3 $\beta$-N16/194Q-R lacking both glycosylation sites appeared as a single band of $39 \mathrm{kDa}$. The molecular-mass difference of roughly $2000 \mathrm{Da}$ between each of the different bands corresponds to the mass of the core glycosylation. Thus the three bands of the wild-type receptor most probably correspond to the unglycosylated, mono-core-glycosylated and dicore-glycosylated receptor proteins. It was intriguing that no smear was observed at higher molecular masses, indicating that complex more highly glycosylated receptor proteins were not detectable. It appeared that, irrespective of the presence or absence of the N-glycosylation sites in transiently transfected cells, most of the receptor protein was retained within the ER without further processing in the Golgi apparatus. This was confirmed by confocal laser-scanning immunofluorescence microscopy.

Neither the wild-type EP3 $\beta$-R (Figure 2A, panel a) nor the non-glycosylated EP3 $\beta$-N16/194Q-R (results not shown) were found in the plasma membrane, which was labelled by biotinylation of the intact vital cells. Receptor proteins were also not found in the Golgi apparatus, which was labelled with an antibody against the Golgi-specific KDEL receptor (Figure 2A, panel c). However, receptor protein was detected in the perinuclear zone of the cell and partially co-localized with the ERspecific marker protein calreticulin (Figure 2A, panel e). It seems unlikely that this localization is artifactual, since in the same system the $\beta$-adrenergic receptor was inserted correctly into the plasma membrane (Figure $2 \mathrm{~A}$, panels $\mathrm{b}$, $\mathrm{d}$ and $\mathrm{f}$ ). The retention of the EP3 $\beta$ - R in the ER was not a cell-specific phenomenon: EP3 $\beta$-R (Figure 2B, panels g, i and k) and EP3 $\beta$-N16/194Q-R (results not shown) were retained in the ER when the receptor constructs were transiently transfected into HeLa cells, COS-7 cells or HepG2 cells. By contrast, in all three cell lines the $\beta$ adrenergic receptor was correctly inserted into the plasma membrane (Figure 2B, panels $\mathrm{h}, \mathrm{j}$ and $\mathrm{l}$ ).

It was the aim of the study to analyse the influence of the $\mathrm{N}$ glycosylation on the subcellular distribution of the receptor protein, therefore transiently transfected cells turned out to be an unsuitable system for the purpose of the study. Thus cell lines stably expressing the receptor proteins were established. Two cell lines were selected for all subsequent studies: EP3 $\beta$-HEK cells, expressing the wild-type receptor, and EP3 $\beta$-N16/194QHEK cells, expressing the mutant lacking both glycosylation

(C) EP3 $\beta$-HEK cells and EP3 $\beta$-N16/194Q-HEK cells were cultured on coverslips. Where indicated, $1 \mu \mathrm{g} / \mathrm{ml}$ tunicamycin was included in the medium for the last 24 h of culture (panels q and r). Plasmamembrane proteins were labelled as described above. Receptor proteins were detected with a polyclonal antiserum against the N-terminal receptor domain and a Cy3-coupled secondary antibody. The wild-type receptor was located in the plasma membrane and in the super-imposition picture appeared as a yellow line around the cell body (panel m). The mutant lacking both glycosylation sites was retained in the perinuclear region and appeared as a narrow red ring around the nucleus (panel n). In tunicamycin-treated cells, the wild-type receptor disappeared from the plasma membrane and accumulated in the perinuclear region (panel q), similar to the receptor lacking the glycosylation sites (panels $n$ and $r$ ). In untransfected control cells a dotty red unspecific staining was found that was most prominent in the region of the nucleus (panel $u$ ). Phase-contrast images indicate localization of the nucleus in each cell (panels 0 , $p$, $s$ and $t$ ). 

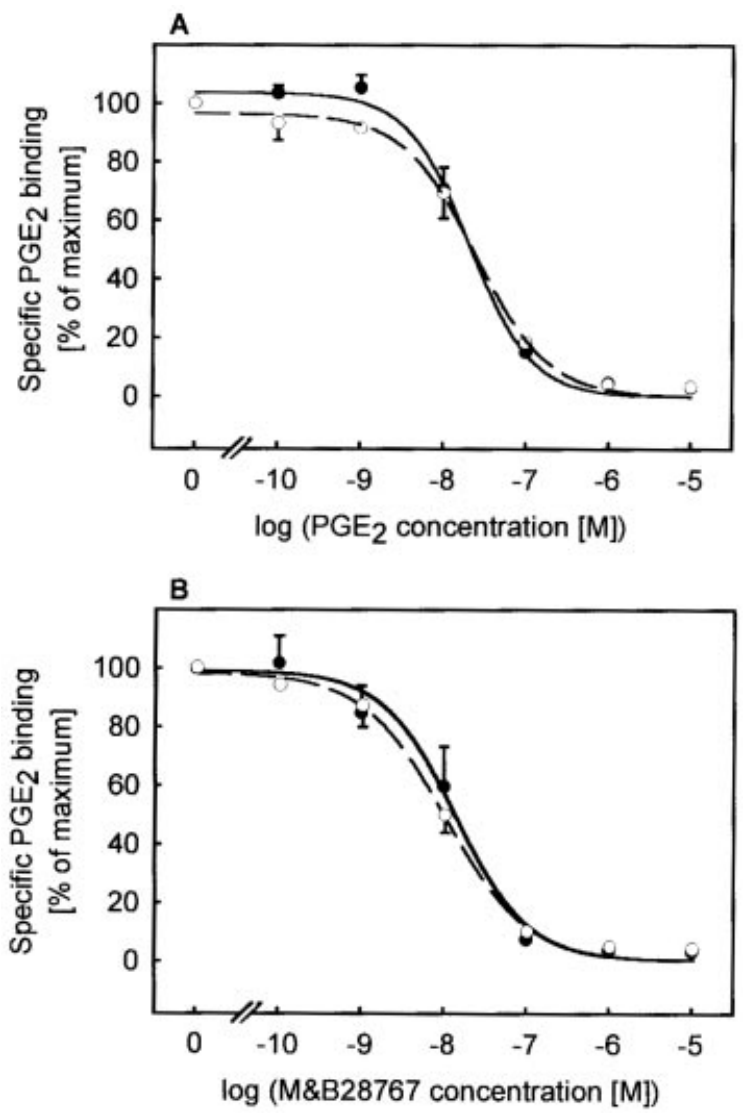

Figure 3 Binding characteristics of EP3 $\beta$-R and EP3 $\beta$-N16/194Q-R

Crude membranes were prepared from EP $3 \beta$-HEK cells and EP3 $\beta$-N16/194Q-HEK cells. Membrane protein $(20-50 \mu \mathrm{g})$ was incubated with $5 \mathrm{nM}\left[{ }^{3} \mathrm{H} \mathrm{PGE}_{2}\right.$ and the indicated concentration of either unlabelled $\mathrm{PGE}_{2}(\mathbf{A})$ or the EP3-R-specific agonist M\&B 28767 (B). Bound and free ligand was separated by rapid vacuum filtration. Unspecific binding was determined in the presence of $10 \mu \mathrm{M} \mathrm{PGE}$. Total binding minus unspecific binding was set at $100 \%$. $K_{\mathrm{d}}$ values calculated by non-linear regression analysis (LIGAND [14]) are $5.19 \pm 0.4 \mathrm{nM}\left(\mathrm{PGE}_{2}\right)$ and $2.92 \pm 0.53 \mathrm{nM}(\mathrm{M} \& \mathrm{~B}$ 28767) for the EP3 $\beta-\mathrm{R}(\mathbf{O})$ and $8.29 \pm 2.8 \mathrm{nM}\left(\mathrm{PGE}_{2}\right)$ and $3.57 \pm 1.4 \mathrm{nM}(\mathrm{M} \& \mathrm{~B}$ 28767) for the EP3 $\beta-\mathrm{N} 16 / 194 \mathrm{Q}-\mathrm{R}(\mathrm{O})$. Values are means \pm S.E.M. from three experiments in triplicate. The apparent difference between the concentration at which unlabelled ligands replaced $50 \%$ of the maximum bound labelled ligand and the calculated $K_{\mathrm{d}}$ value is due to the fact that the concentration of labelled ligand $(5 \mathrm{nM})$ was higher than the $K_{d}$ value.

sites. Membranes of both cell lines bound $\mathrm{PGE}_{2}$ with about the same maximum specific binding of $5.35 \pm 0.51$ and $4.91 \pm 0.79 \mathrm{pmol} / \mathrm{mg}$ of membrane protein respectively (results not shown). Despite approximately identical receptor-protein concentrations in both cell lines under steady-state conditions, the level of receptor mRNA as determined by Northern-blot analysis and the rate of receptor-protein synthesis as determined by incorporation of $\left[{ }^{35} \mathrm{~S}\right] \mathrm{Met} / \mathrm{Cys}$ in immunoprecipitated receptor protein was about twice as high in EP3 $\beta$-N16/194Q-HEK cells than in EP3 $\beta$-HEK cells (results not shown). On the other hand, the non-glycosylated receptor appeared to have an approx. $40 \%$ shorter half-life than the wild-type receptor, as determined by pulse-chase experiments and immunoprecipitation with either the antibody against the FLAG epitope or a polyclonal antiserum against the C-terminal receptor domain (results not shown).

The receptor proteins produced by the two stably transfected cell lines did not differ in their affinity for $\mathrm{PGE}_{2}$ or the EP3specific ligand M\&B 28767 (Figure 3). Both receptor proteins coupled efficiently to $G_{i}$. The EP3-specific agonist M\&B 28767

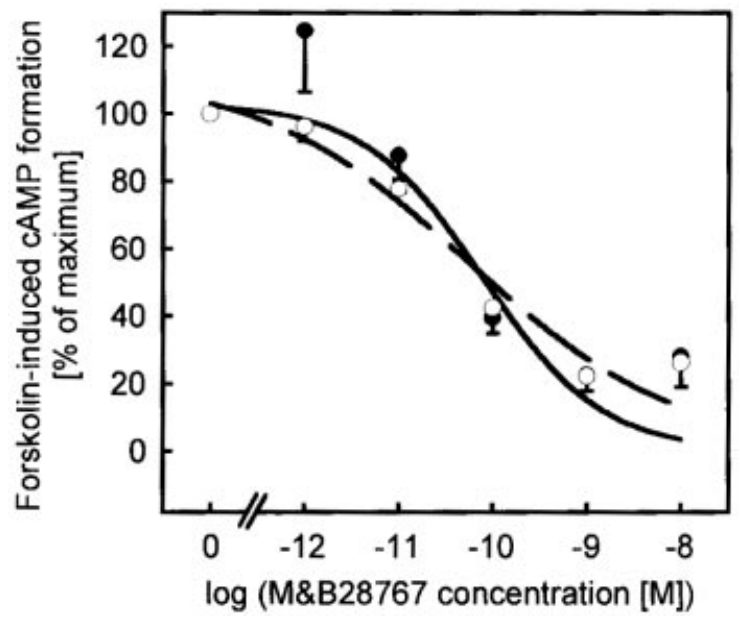

Figure 4 Inhibition of forskolin-induced CAMP formation by EP3 $\beta$-HEK cells and EP3 $\beta$-N16/194Q-HEK cells

EP3 $\beta$-HEK cells and EP3 $\beta$-N16/194Q-HEK cells were grown to confluence on $8.7-\mathrm{cm}^{2}$ plates Cells were washed with serum-free incubation medium and then incubated for $10 \mathrm{~min}$ in this medium containing $10 \mu \mathrm{M}$ forskolin and the concentration of the specific agonist M\&B 28767 indicated. Cellular CAMP was determined by radioimmunoassay as described in the Experimental procedures section. The maximal CAMP concentration after stimulation with forskolin was set at $100 \%$ in each experiment. The $\mathrm{EC}_{50}$ value for $\mathrm{EP} 3 \beta$-R $(\mathbf{O})$ was $72.6 \pm 28 \mathrm{pM}$ and for $\mathrm{EP} 3 \beta$ N16/194Q-R (O) $55.5 \pm 24 \mathrm{pM}$. Values are means \pm S.E.M. from three independent experiments.

decreased forskolin-stimulated cAMP formation with the same apparent $\mathrm{EC}_{50}$ in both cell lines (Figure 4).

Western-blot analysis revealed a different pattern of receptorspecific bands in stably transfected cells compared with transiently transfected cells (Figure 5). In stably transfected cells receptor proteins could not be detected with the FLAG-M2 antibody, even though the coding sequence for the FLAG epitope was present in-frame in the mRNA in stably transfected cells, as verified by sequencing of cDNA (results not shown). Therefore, a polyclonal antiserum against the $\mathrm{C}$-terminal or $\mathrm{N}$ terminal domains had to be used for immunological detection in these experiments. With this antiserum, the wild-type receptor in transiently transfected cells appeared as a main band of $43 \mathrm{kDa}$ (Figure 5), with minor bands at 41 and $39 \mathrm{kDa}$ (see above) corresponding to the core bi-, mono- and unglycosylated receptor proteins. As with the FLAG-M2 antibody (Figure 1), no bands of higher molecular mass corresponding to complex more highly glycosylated receptor proteins were detected. In stably transfected cells, by contrast, the wild-type receptor migrated as a broad smear around $60 \mathrm{kDa}$, and only faint bands around $40 \mathrm{kDa}$ were observed (Figure 5). After treatment of the cell lysates with protein $\mathrm{N}$-glycosidase $\mathrm{F}$, the smear at $60 \mathrm{kDa}$ disappeared and a sharp band of $39 \mathrm{kDa}$ appeared instead, which migrated at the same altitude as the receptor protein lacking both glycosylation sites and, thus, most probably corresponded to the unglycosylated protein. The results indicate that the EP $3 \beta$-R, which was retained in the ER in transiently transfected cells, passed through the Golgi apparatus where it underwent complex glycosylation in stably transfected cells. This was confirmed by confocal laser-scanning immunofluorescence microscopy.

Intact EP3 $\beta$-HEK cells or EP3 $\beta$-N16/194Q-HEK cells were biotinylated to label the plasma membrane. Cells were then fixed and permeabilized and the receptor proteins were detected with a polyclonal antiserum against the $\mathrm{N}$-terminal receptor domain 


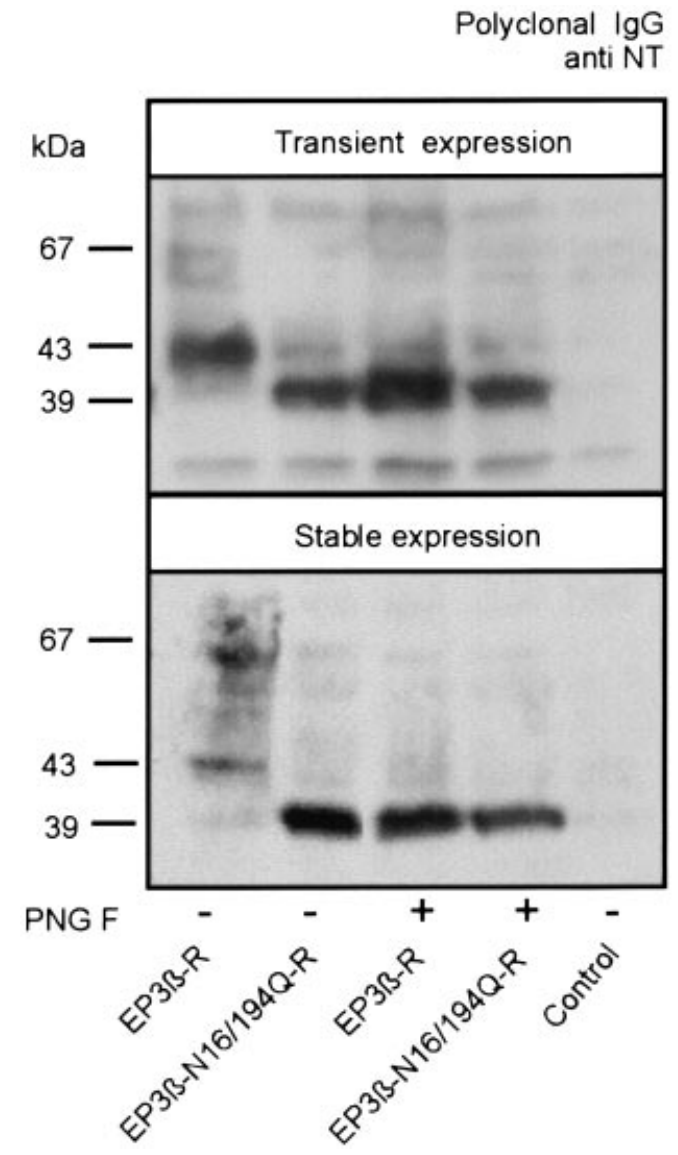

Figure 5 Comparison of the apparent molecular masses of EP3 $\beta$-R and EP3 $\beta$-N16/194Q-R in stably and transiently transfected cells

Crude membranes were isolated by differential centrifugation from cells transiently transfected with $\mathrm{EP} 3 \beta$ - $\mathrm{R}$ or $\mathrm{EP} 3 \beta-\mathrm{N} 16 / 194 \mathrm{Q}-\mathrm{R}$ as described in Figure 1 or from stably transfected cell grown to confluency. Membrane protein $(100 \mu \mathrm{g})$ was incubated in SDS sample buffer in either the presence or absence of protein N-glycosidase F (PNG F). Proteins were separated on a 10\% polyacrylamide gel and transferred on to PVDF membranes by electroblotting. Receptor proteins were detected with a peptide-specific polyclonal antiserum against the $15 \mathrm{~N}$-terminal amino acids of the EP3 $\beta$-R (polyclonal IgG anti-NT). Blots were developed with a peroxidase-coupled secondary antibody and the ECL system.

and a Cy3-labelled secondary antibody (Figure 2C, panels $\mathrm{m}$ and n). Although the two cell clones were obtained by single-cell cloning, they appeared not to be homogenous. In both cell lines receptor-protein-specific staining was detected in only about one-third of all cells (Table 2). Roughly one-half of this fraction showed a strong staining for the receptor. In EP $3 \beta$-HEK cells the receptor protein was located in the plasma membrane in all cells that expressed the receptor (Figure $2 \mathrm{C}$, panel $\mathrm{m}$ ). In about onehalf of this cell fraction an additional perinuclear localization of the receptor protein was observed. There were no EP3 $\beta$-HEK cells showing an exclusive perinuclear receptor localization (Table $2)$. By contrast, no receptor protein was detected in the plasma membrane of EP3 $\beta$-N16/194Q-HEK cells (Figure 2C, panel n). In these cells, the receptor protein was found exclusively in the perinuclear region. If EP $3 \beta$-HEK cells were treated with tunicamycin, an inhibitor of N-glycosylation, for $24 \mathrm{~h}$, the percentage of cells with a plasma-membrane localization of the receptor decreased considerably (Table 2). In contrast to untreated cells, after tunicamycin treatment EP3 $\beta$-HEK cells with exclusive perinuclear receptor location were found (Figure

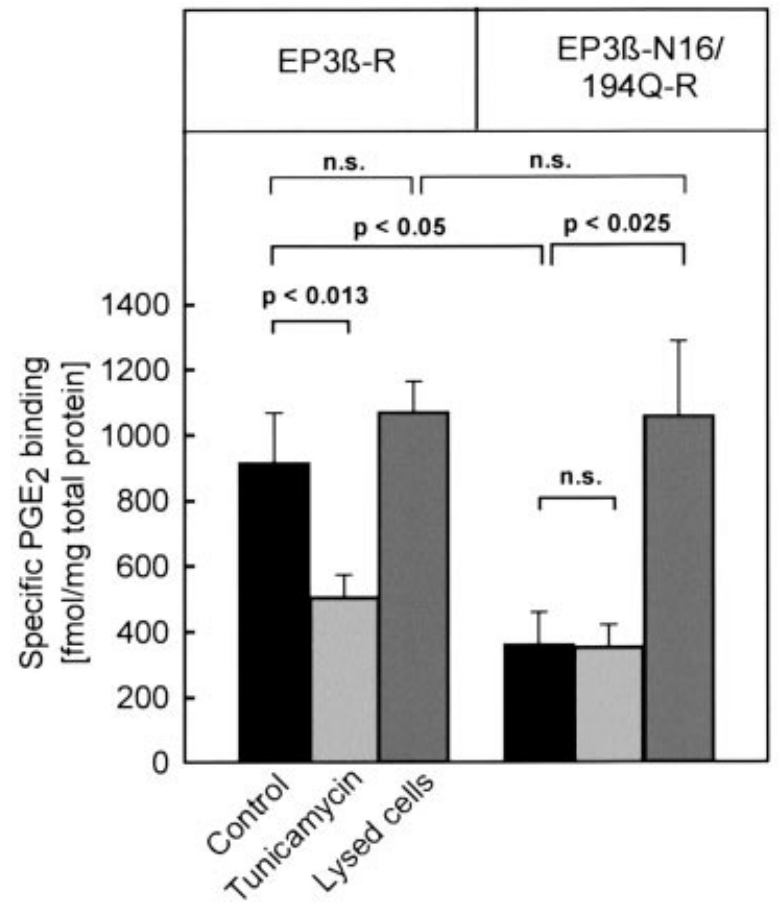

Figure 6 Reduction by tunicamycin treatment of $\mathrm{PGE}_{2}$ binding to intact cells stably expressing EP3 $\beta$-R but not in cells expressing EP3 $\beta$-N16/ 194Q-R

Cells stably expressing either EP3 $\beta$-R or EP3 $\beta$-N16/194Q-R were grown to confluency on $8.7-\mathrm{cm}^{2}$ plates. Cells were washed and then incubated for $1 \mathrm{~h}$ at $4{ }^{\circ} \mathrm{C}$ with $5 \mathrm{nM}$ $\left[{ }^{3} \mathrm{H}_{\mathrm{PGE}} \pm 10 \mu \mathrm{M}\right.$ unlabelled $\mathrm{PGE}_{2}$ to determine unspecific binding. Culture plates were washed three times with ice-cold incubation medium and solubilized in $5 \%$ Triton X-100. The radioactivity in the solubilizate was determined. Parallel plates were lysed for protein determination. Values are means \pm S.E.M. from four experiments. Binding to lysed cells was determined by preparing a cell homogenate that was assayed in a filter-binding assay as described in Figure 3.

2C, panel q). These data indicate that the N-glycosylation is required for efficient receptor translocation to the plasma membrane. This was confirmed further by binding studies with intact cells.

Intact EP3 $\beta$-HEK cells or EP3 $\beta$-N16/194Q-HEK cells were incubated at $4{ }^{\circ} \mathrm{C}$ with $5 \mathrm{nM}\left[{ }^{3} \mathrm{H}\right] \mathrm{PGE}_{2}$ for $1 \mathrm{~h}$ to allow binding to $\mathrm{PGE}_{2}$ receptors on the cell surface. Cells were then washed three times to remove unbound radioactivity. The cell-associated radioactivity was counted. Unspecific binding was determined in the presence of excess unlabelled $\mathrm{PGE}_{2}$. In intact EP $3 \beta$-HEK cells, three times the number of receptors was accessible at the cell surface as in EP3 $\beta$-N16/194Q-HEK cells (Figure 6). If cells were lysed prior to incubation with $\left[{ }^{3} \mathrm{H}\right] \mathrm{PGE}_{2}$ this difference was abolished. If EP3 $\beta$-HEK cells were treated with the inhibitor of $\mathrm{N}$-glycosylation tunicamycin the number of $\left[{ }^{3} \mathrm{H}\right] \mathrm{PGE}_{2}$ binding sites was reduced by $50 \%$, whereas tunicamycin treatment had no effect on the number of surface-accessible $\mathrm{PGE}_{2}$-binding sites in EP3 $\beta$-N16/194Q-HEK cells (Figure 6).

\section{DISCUSSION}

\section{Role of $\mathrm{N}$-glycosylation for correct folding of the EP3 $\beta$-R protein}

$\mathrm{N}$-glycosylation begins co-translationally as soon as the potential glycosylation sites of the nascent protein have traversed the 


\section{Table 2 Subcellular distribution of EP3 $\beta$-R and EP3 $\beta$-N16/194-R}

EP3 $\beta$-HEK cells and EP3 $\beta$-N16/194Q-HEK cells were cultured on coverslips, fixed and labelled with polyclonal lgG against the EP3 $\beta$-R N-terminal domain and a Cy3-labelled secondary antibody. Plasma membranes were stained by biotinylation of the living intact cells and a streptavidin-FITC conjugate. In parallel, cells were treated with $1 \mu \mathrm{g} / \mathrm{ml}$ tunicamycin for $24 \mathrm{~h}$ and labelled as described. The slides were analysed by confocal laser-scanning microscopy and stained cells were counted. TM, tunicamycin.

\begin{tabular}{|c|c|c|c|c|c|c|c|c|}
\hline & \multicolumn{4}{|c|}{$\mathrm{EP} 3 \beta-\mathrm{R}$} & \multicolumn{4}{|c|}{ EP3 $\beta$-N16/194Q-R } \\
\hline & \multicolumn{2}{|c|}{$-\mathrm{TM}$} & \multicolumn{2}{|c|}{$+\mathrm{TM}$} & \multicolumn{2}{|c|}{$-\mathrm{TM}$} & \multicolumn{2}{|c|}{$+\mathrm{TM}$} \\
\hline & No. & $\%$ & No. & $\%$ & No. & $\%$ & No. & $\%$ \\
\hline Cells counted & 201 & 100 & 236 & 100 & 177 & 100 & 195 & 100 \\
\hline Localization in plasma membrane & 68 & 34 & 13 & 5.5 & 0 & 0 & 0 & 0 \\
\hline Strong staining & 30 & 15 & 0 & 0 & 0 & 0 & 0 & 0 \\
\hline Perinuclear localization & 26 & 13 & 44 & 19 & 66 & 37 & 64 & 33 \\
\hline Strong staining & 0 & 0 & 0 & 0 & 21 & 12 & 9 & 5 \\
\hline Number of experiments & 2 & & 2 & & 2 & & 2 & \\
\hline
\end{tabular}

membrane of the ER [15]. In many cases, N-glycosylation in the ER is a prerequisite for correct folding of the nascent protein [16]. N-glycosylation prevents precipitation and self-aggregation of the nascent protein by increasing hydrophilicity and by shielding of hydrophobic interactions [17]. In addition, Nglycosylation in some cases allows the interaction with lectin-like domains in chaperones [17]. The requirement of N-glycosylation for correct folding of heptahelical receptors can be assessed indirectly by determining receptor functions depending on correct folding such as ligand-binding affinity and signal-transduction activity. Heptahelical G-protein-coupled receptors are heterogeneous in their requirement for $\mathrm{N}$-glycosylation. Whereas some receptors exist that do not have natural $\mathrm{N}$-glycosylation sites, e.g. the $\alpha 2$-adrenergic receptor [18], for some heptahelical receptors $\mathrm{N}$-glycosylation appears to be essential for the synthesis of an active protein. Such an example is rhodopsin, which needs to be N-glycosylated in order to activate phosphodiesterase in response to light [19]. In other cases, for example the somatostatin receptor, $\mathrm{N}$-glycosylation is not required for signal transduction yet is essential for high-affinity ligand binding and hence seems to be required to form a correct binding pocket [20]. By contrast, elimination of $\mathrm{N}$-glycosylation sites from, for example, the $\beta$ adrenergic receptor by site-directed mutagenesis resulted in a fully functional receptor protein with normal affinity for its ligand [10]. The results obtained in this study indicate that the $\mathrm{EP} 3 \beta$-R belongs to this latter group. There was no difference in ligand-binding affinity between the wild-type $\mathrm{EP} 3 \beta$ - R and the EP $3 \beta$ N16/194Q-R in which both N-glycosylation sites had been eliminated (Figure 3). Both receptor proteins coupled to $G_{i}$ and decreased forskolin-stimulated cAMP formation with an identical $\mathrm{EC}_{50}$ (Figure 4). However, these results are at variance with results that have been reported previously for the EP $3 \alpha-\mathrm{R}$ that had been transiently overexpressed with the baculovirus system in insect cells [13]. In this expression system, elimination of the distal $\mathrm{N}$-glycosylation site resulted in a receptor protein that displayed reduced affinity for $\mathrm{PGE}_{2}$. It is unlikely that this difference between the current and the previous study can be attributed to the different $\mathrm{C}$-terminal domains of the two receptor proteins that are generated by differential splicing. Rather, differences in the expression systems may be the cause of the difference observed. N-glycosylation end products from $\mathrm{Sf} 9$ cells differ from those obtained in mammalian cell lines [21,22]. Besides major differences in the trimming reactions there appears to be no significant sialylation of $\mathrm{N}$-glycans in insect cells. The discrepancy observed between the two studies might also be attributed to differences in the proof-reading system for proteins in the ER. It seems reasonable to assume that in HEK cells the mammalian protein proof-reading system in the ER will eliminate a mammalian receptor protein that has been misfolded due to a lack of glycosylation, whereas in insect cells such proof-reading might not occur or might be less efficient, and hence a defective protein may exit from the protein-synthesis machinery. The observation that EP3 $\beta$-N16/194Q-HEK cells had a similar number of binding sites per cell, despite an approx. 2-fold higher rate of de novo synthesis of receptor protein and the reduced halflife of the EP3 $\beta$-N16/194Q-R protein, might point in this direction. The lack of glycosylation sites might have favoured the synthesis of misfolded receptor protein, which, however, was eliminated immediately by the ER proof-reading system.

\section{Requirement of $\mathrm{N}$-glycosylation for transport of the EP3 $\beta$-R protein to the plasma membrane}

The transport of glycoproteins often depends on the correct glycosylation. This is due in part to the retention in the ER of non- or partly glycosylated and improperly folded proteins by the quality-control machinery of the ER [23]. In addition, carbohydrate moieties often fulfil a function as tags for the correct sorting of proteins to their subcellular target [24-28]. Interestingly, it was not possible to study the role of $\mathrm{N}$ glycosylation for the subcellular sorting of the EP3 $\beta$-R in transiently transfected cells, since the bulk of the receptor protein, both of the wild-type receptor (Figures 2A, panel e, and 2B, panels $\mathrm{g}$, $\mathrm{i}$ and $\mathrm{k}$ ) and the glycosylation-deficient mutant, accumulated in the ER irrespective of the cell line used for expression. By contrast, the wild-type receptor was inserted correctly into the plasma membrane in stably transfected cells (Figure 2C). The wild-type receptor protein in transiently transfected cells apparently was core-glycosylated (Figure 1); however, there were no indications of complex modifications of the sugar side chains. A similar dependence of the receptor localization and processing of the carbohydrate moieties on the expression system was found for the V2 vasopressin receptor [29]. After transient expression, this receptor lacked complex sugar modifications and was retained in the ER, whereas the receptor was correctly processed and sorted after stable transfection. Apparently, excessive overexpression of receptor proteins as obtained by transient transfection can saturate the rate-limiting step of carbohydrate processing in the ER [30] and prevent the translocation of the newly synthesized receptor protein to the Golgi apparatus for further processing. This seems not to be a general phenomenon, since the $\beta$-adrenergic receptor was trans- 
located efficiently to the plasma membrane after transient transfection (Figure 2A, panel b). However, the receptor protein similar to the EP3 $\beta$-R lacked complex glycosylation to a large extent, as judged by the discrete band that was seen in the Western blot at an apparent molecular mass corresponding to the core-glycosylated receptor (results not shown).

G-protein-coupled receptors appear to be heterogeneous, not only in their requirement of glycosylation for correct folding but also in their requirement of glycosylation for efficient translocation of the receptor protein to the plasma membrane. Whereas the insertion into the plasma membrane of some receptors, e.g. the dopamine D1 receptor [31] or the glucagon receptor [32], seems to be independent of glycosylation, for others, e.g. angiotensin AT1-R [33], the dopamine D5 receptor [31] or the $\beta$-adrenergic receptor [10], glycosylation seems to be essential for the efficient translocation to the plasma membrane. The EP $3 \beta$-R appears to belong to the latter group. Elimination of the glycosylation sites by site-directed mutagenesis or suppression of N-glycosylation by tunicamycin treatment resulted in an accumulation of the immunoreactive receptor protein in the perinuclear zone of the ER (Figure 2C, panels $n$ and q; Table 2) and a reduction of surface-accessible binding sites in intact cells (Figure 6). This indicates that the correct translocation of the $\mathrm{EP} 3 \beta$-R to the plasma membrane depended on receptor $\mathrm{N}$ glycosylation. Immunocytochemically, no receptor protein was detectable at the plasma membrane, while some binding occurred in intact cells, implying that some receptor is present at the plasma membrane. This apparent discrepancy could be explained in two ways. Either the receptor concentration on the cell surface was too low for immunocytochemical detection or some of the ligand had access to receptor within the cell, due either to leakage of apparently intact cells or to a limited permeability of the intact cell to the lipophilic ligand $\mathrm{PGE}_{2}$.

In conclusion, the $\mathrm{EP} 3 \beta-\mathrm{R}$ has two potential $\mathrm{N}$-glycosylation sites, both of which are used. Glycosylation of the receptor is not a prerequisite for proper folding of a functional receptor protein but appears to be essential for efficient translocation of the receptor protein to the plasma membrane.

This work was supported by the Deutsche Forschungsgemeinschaft through the Sonderforschungsbereich 402, Teilprojekt B6 and the Graduiertenkolleg 41 (fellowship to U. B.), and by Fonds der Chemischen Industrie. The invaluable advice of Professor $\mathrm{K}$. Jungermann is gratefully acknowledged.

\section{REFERENCES}

1 Narumiya, S. (1994) Prostanoid receptors. Structure, function, and distribution. Ann. N.Y. Acad. Sci. 744, 126-138

2 Coleman, R. A., Smith, W. L. and Narumiya, S. (1994) International Union of Pharmacology classification of prostanoid receptors: properties, distribution and structure of the receptors and their subtypes. Pharmacol. Rev. 46, 205-229

3 Thierauch, K. H., Dinter, H. and Stock, G. (1994) Prostaglandins and their receptors II. Receptor structure and signal transduction. J. Hypertens. 12, 1-5

4 Tai, H., Huang, C. and Chiang, N. (1997) Structure and function of prostanoid receptors as revealed by site-directed mutagenesis. Adv. Exp. Med. Biol. 407 205-209

5 Audoly, L. and Breyer, R. M. (1997) Substitution of charged amino acid residues in transmembrane regions 6 and 7 affect ligand binding and signal transduction of the prostaglandin EP3 receptor. Mol. Pharmacol. 51, 61-68

6 Audoly, L. and Breyer, R. M. (1997) The second extracellular loop of the prostaglandin EP3 receptor is an essential determinant of ligand selectivity. J. Biol. Chem. 272, 13475-13478

7 Neuschaefer-Rube, F., Haenecke, K., Blaschke, V., Jungermann, K. and Pueschel, G. P. (1996) The C-terminal domain of the Gs-coupled EP4 receptor confers agonistdependent coupling control to Gi but no coupling to Gs in a receptor hybrid with the Gi-coupled EP3 receptor. FEBS Lett. 401, 185-190
8 Neuschaefer-Rube, F., DeVries, C., Haenecke, K., Jungermann, K. and Pueschel, G. P. (1994) Molecular cloning and expression of a prostaglandin $E_{2}$ receptor of the EP3 $\beta$ subtype from rat hepatocytes. FEBS Lett. 351, 119-122

9 Yatsunami, K., Fujisawa, J., Hashimoto, H., Kimura. K. Takahashi, S. and Ichikawa, A. (1990) Effect of tunicamycin on functions of $P G E_{1}$-receptors from mouse mastocytoma P815 cells. Biochem. Biophys. Acta. 1051, 94-99

10 Rands, E., Candelore, M. R., Cheung, A. H., Hills, W. S., Strader, C. D. and Dixon, R. A. (1990) Mutational analysis of $\beta$-adrenergic receptor glycosylation. J. Biol. Chem. 265, 10759-10764

11 van-Koppen, C. J. and Nathanson, N. M. (1990) Site-directed mutagenesis of the m2-muscarinic acetylcholin receptor. J. Biol. Chem. 265, 20887-20892

12 Fukushima, Y., Oka, Y., Saitoh, T., Katagiri, H., Asano, T., Matsuhashi, N., Takata, K., van Breda, E., Yazaki, Y. and Sugano, K. (1995) Structural and functional analysis of the canine histamine $\mathrm{H} 2$ receptor by site-directed mutagenesis: $\mathrm{N}$-glycosylation is not vital for its action. Biochem. J. 310, 553-558

13 Huang, C. and Tai, H. H. (1998) Prostaglandin E2 receptor EP3alpha subtype: the role of $\mathrm{N}$-glycosylation in ligand binding as revealed by site-directed mutagenesis. Prostaglandins Leukot. Essent. Fatty Acids 59, 265-271

14 Munson, P. J. and Rodbard, D. (1980) A versatile computerized approach for characterization of ligand-binding systems. Anal. Biochem. 107, 220-239

15 Kornfeld, R. and Kornfeld, S. (1985) Assembly of asparagine-linked oligosaccharides. Annu. Rev. Biochem. 54, 631-664

16 Helenius, A. (1994) How N-linked oligosaccharides affect glycoprotein folding in the endoplasmic reticulum. Mol. Biol. Cell. 5, 253-265

17 Rudd, P. M. and Dwek, R. A. (1997) Glycosylation: heterogeneity and the 3D structure of proteins. Crit. Rev. Biochem. Mol. Biol. 32, 1-100

18 Weinshank, R.L, Zgombick, J. M., Macchi, M., Adham, N., Lichtblau, H., Branchek, T. A. and Hartig, P. R. (1990) Cloning, expression, and pharmacological characterization of a human alpha 2B-adrenergic receptor. Mol. Pharmacol. $\mathbf{3 8}$ 681-688

19 Kaushal, S., Ridge, K. D. and Khorana, H. G. (1994) Structure and function in rhodopsin: the role of asparagine-linked glycosylation. Proc. Natl. Acad. Sci. U.S.A. 91, 4024-4028

20 Rens-Domiano, S. and Reisine, T. (1991) Structural analysis and functional role of the carbohydrate component of somatostatin receptors. J. Biol. Chem. 266 20094-20102

21 Jarvis, D. L. and Finn, E. E. (1995) Biochemical analysis of the N-glycosylation pathway in baculovirus-infected lepidopteran insect cells. Virology 212, 500-511

22 Altmann, F., Staudacher, E., Wilson, I. B. and Marz, L. (1999) Insect cells as hosts for the expression of recombinant glycoproteins. Glycoconj. J. 16, 109-123

23 Hammond, C. and Helenius, A. (1995) Quality control in the secretory pathway. Curr. Opin. Cell Biol. 7, 523-529

24 Kornfeld, S. (1987) Trafficking of lysosomal enzymes. FASEB J. 1, 462-468

25 Benting, J. H., Rietveld, A. G. and Simons, K. (1999) N-Glycans mediate the apical sorting of a GPI-anchored, raft-associated protein in Madin-Darby canine kidney cells. J. Cell Biol. 146, 313-320

26 Zheng, X., Lu, D. and Sadler, J. E. (1999) Apical sorting of bovine enteropeptidase does not involve detergent-resistant association with sphingolipid-cholesterol rafts. J. Biol. Chem. 274, 1596-1605

27 Gut, A., Kappeler, F., Hyka, N., Balda, M. S., Hauri, H. P. and Matter, K. (1998) Carbohydrate-mediated Golgi to cell surface transport and apical targeting of membrane proteins. EMBO J. 17, 1919-1929

28 Scheiffele, P., Peranen, J. and Simons, K. (1995) N-glycans as apical sorting signals in epithelial cells. Nature (London) 378, 96-98

29 Innamorati, G., Sadeghi, H. and Birnbaumer, M. (1996) A fully active nonglycosylated V2 vasopressin receptor. Mol. Pharmacol. 50, 467-473

30 Hooker, A. D., Green, N. H., Baines, A. J., Bull, A. T., Jenkins, N., Strange, P. G. and James, D. C. (1999) Constraints on the transport and glycosylation of recombinant IFN-gamma in Chinese hamster ovary and insect cells. Biotechnol. Bioeng. 63 , 559-572

31 Karpa, K. D., Lidow, M. S., Pickering, M. T., Levenson, R. and Bergson, C. (1999) $\mathrm{N}$-linked glycosylation is required for plasma membrane localization of D5, but not D1, dopamine receptors in transfected mammalian cells. Mol. Pharmacol. $\mathbf{5 6}$, 1071-1078

32 Unson, C. G., Cypess, A. M., Kim, H. N., Goldsmith, P. K., Carruthers, C. J., Merrifield, R. B. and Sakmar, T. P. (1995) Characterization of deletion and truncation mutants of the rat glucagon receptor. Seven transmembrane segments are necessary for receptor transport to the plasma membrane and glucagon binding. J. Biol. Chem. 270, 27720-27727

33 Lanctot, P. M., Leclerc, P. C., Escher, E., Leduc, R. and Guillemette, G. (1999) Role of $\mathrm{N}$-glycosylation in the expression and functional properties of human AT1 receptor. Biochemistry 38, 8621-8627

Received 24 March 2000/16 June 2000; accepted 13 July 2000 